\title{
PENERAPAN MODEL PEMBELAJARAN INQUIRY TRAINING BERBASIS MIND MAPPING UNTUK MENINGKATKAN HASIL BELAJAR FISIKA PADA MATERI POKOK SUHU DAN KALOR DI SMA N 1 SIMANINDO
}

\author{
Setia Rumahorbo dan Eidi Sihombing \\ Jurusan Fisika FMIPA Universitas Negeri Medan \\ Jalan Willem Iskandar Pasar V Medan, Sumatera Utara \\ setiarumahorbo92.sr@gmail.com
}

\begin{abstract}
ABSTRAK
Penelitian ini bertujuan untuk mengetahui penerapan model pembelajaran inquiry training berbasis mind mapping terhadap hasil belajar fisika pada materi suhu dan kalor di kelas X SMA Negeri 1 Simanindo T.P. 2014/2015. Jenis penelitian ini adalah quasi experiment. Metode penelitian yang digunakan yaitu pre-eksperimental design dengan rancangan one group pretest-postest design. Populasi dalam penelitian adalah seluruh siswa kelas X SMA N 1 Simanindo T.P 2014/2015 yang terdiri dari 5 kelas. Pengambilan sampel dilakukan dengan cara cluster random sampling dengan mengambil 1 kelas yaitu kelas X B sebagai kelas eksperimen yang berjumlah 36 orang. Instrumen yang digunakan untuk mengetahui hasil belajar siswa adalah tes hasil belajar yang berbentuk essay test dengan jumlah 8 soal. Hasil uji McNemar memperlihatkan adanya perubahan kemampuan siswa yang signifikan dalam menyelesaikan soal untuk semua indikator soal tes, dimana $x^{2}$ tabel $(3,84)<x^{2}$ hitung $(19,06)$ untuk db $=1$ dan $a=$ 0,05, sehingga dapat disimpulkan bahwa ada pengaruh model pembelajaran inquiry training berbasis mind mapping terhadap hasil belajar siswa.
\end{abstract}

Kata kunci : model pembelajaran inquiry training, suhu dan kalor

\begin{abstract}
This study aims to determine the implementation of inquiry training model based mind mapping outcomes of physics in the subject matter of the heat and temperature topic in class X SMA Negeri 1 Simanindo T.P. 2014/2015. This research is a quasi experimental. The method used pre-experimental design with the design of one group pretest-posttest design. Population in the study were all students of class X SMA N 1 Simanindo T.P. 2014/2015 consist of 5 classes. The sample of this research difine by cluster random sampling taking one class, namely the class $X B$ as an experimental class, numbering 36 people. Instrument used to determine student learning outcomes is the achievement test form of essay test which amounts 8 questions. McNemar test results showed significant changes in the student's ability in solving test questions for all indicators, where $x^{2}$ table (3.84) <
\end{abstract}


$x^{2}$ count (19.06) for $d b=1$ and $\alpha=0.05$, so it can be concluded that inquiry training model based mind mapping had an effect on student learning outcomes.

Keywords: inquiry training learning model, heat and temperature

PENDAHULUAN

Pendidikan adalah segala
situasi dalam hidup yang
mempengaruhi pertumbuhan
seseorang. Pendidikan adalah
pengalaman belajar atau dapat pula
didefenisikan sebagai keseluruhan
pengalaman belajar setiap orang sepanjang hidupnya. Ditinjau dari bentuk kegiatannya, pendidikan mempunyai ruang lingkup yang terentang dari bentuk-bentuk informal yang tidak direncan akan sampai dengan bentuk-bentuk pendidikan formal yang terprogram. Contoh pendidikan formal adalah sekolah atau persekolahan (schooling). Sekolah sebagai lembaga pendidikan formal merupakan salah satu hasil rekayasa dari peradaban manusia, di samping keluarga, dunia kerja, negara, dan lembaga keagamaan. Sekolah sebagai hasil rekayasa manusia diciptakan untuk menyelenggarakan pendidikan, dan penciptaannya berkaitan erat dengan penguasaan bahasa tertulis dalam masyarakat, yang berkembang makin sistematis dan meningkat.

Salah satu mata pelajaran yang diajarkan di sekolah, terutama sekolah menengah adalah fisika. Mata pelajaran fisika merupakan mata pelajaran yang berupaya mendidik siswa bukan hanya berilmu namun juga berketerampilan yang unggul, melatih melakukan penelitian sesuai proses ilmiah, memiliki sifat disiplin, jujur, bertanggung jawab, mampu bekerja sama dalam suatu kelompok, serta mampu mengaplikasikan ilmunya dalam kehidupan nyata. Hal inilah yang menjadikan pendekatan keterampilan proses sangat diperlukan karena menekankan pada kegiatan ilmiah, yaitu keterampilan memperoleh pengetahuan dan mengkomunikasikan hasilnya. Kemampuan itu dikembangkan melalui pengalaman langsung dengan melakukan penyelidikan atau percobaan di laboratorium atau kelas, sehingga pelajaran fisika termasuk salah satu pelajaran yang cukup menarik karena langsung berkaitan dengan kejadian yang nyata dan juga dapat diaplikasikan dalam kehidupan sehari-hari (Kurnianto, 2010).

Hasil wawancara yang dilakukan peneliti dengan salah satu guru fisika di SMA Negeri 1 Simanindo Kabupaten Samosir menunjukkan bahwa hasil belajar siswa masih rendah, dimana nilai rata-rata ujian fisika siswa kelas $\mathrm{X}$ semester I dan semester II pada tahun pelajaran 2013/2014 masih rendah, yaitu 56 dan 60. Nilai Kriteria Ketuntasan Minimal mata pelajaran fisika yaitu 70 . Pembelajaran di sekolah tersebut masih berpusat pada guru dimana guru mengajarkan fisika dengan model konvensional dengan metode ceramah dan diskusi, kemudian siswa diminta mengerjakan soal baik secara perorangan ataupun kelompok. Faktor lain penyebab rendahnya hasil belajar siswa dikarenakan siswa jarang dalam melakukan praktikum, sehingga tidak ada keterlibatan siswa baik secara fisik maupun mental (mempraktekkan langsung) dalam proses belajar mengajar. 
$\begin{array}{rlr}\text { Penggunaan } & \text { model } & \text { yang } \\ \text { dilakukan oleh } & \text { guru dalam }\end{array}$ mengajarkan fisika dikatakan masih kurang karena yang sering dilakukan oleh guru adalah metode ceramah dan diskusi. Definisi yang diberikan oleh John Dewy menjelaskan bahwa demokrasi dan pendidikan adalah sudut pandang yang sangat menarik dalam pembangunan manusia. Pendidikan adalah pengembangan semua kapasitas individu yang memungkinkannya untuk mengontrol lingkungannya dan memenuhi kemungkinannya. Menurut Dewy orang berpendidikan mampu mengendalikan lingkungannya sehingga anak-anak harus diberikan kesempatan untuk mengenal tahu tentang berbagai masalah kehidupan untuk mengembangkan kapasitas dan mengendalikan lingkungannya (Kadughothel, 2015).

Berdasarkan pemaparan di atas, salah satu cara yang dapat dilakukan supaya pembelajaran melibatkan siswa adalah menerapkan model pembelajaran inquiry training. Inquiry adalah istilah yang digunakan dalam mengajar ilmu yang mengacu pada cara mempertanyakan, mencari pengetahuan atau informasi atau mencari tahu tentang fenomena yang melibatkan investigasi, mencari masalah, merumuskan hipotesis, mengumpulkan, menginterpretasikan data dan mengambil suatu kesimpulan (Vaishnav, 2013).

Inquiry training dikembangkan oleh Suchman. Teori yang diberikan oleh Suchman menunjukkan berikut: 1) Orang menanyakan secara alami ketika mereka bingung, 2) Mereka dapat menjadi sadar dan belajar untuk menganalisis dan memikirkan strategi, 3) Strategi baru dapat dicari langsung dan ditambahkan ke siswa lain 4) Kerjasama dalam inquiry memperkaya pemikiran dan membantu siswa untuk belajar tentang pengetahuan sementara dan menghargai kemungkinan lain.

Di dalam model pembelajaran inquiry training terdapat lima tahapan, yaitu 1) menghadapkan siswa kepada masalah, 2) mengumpulkan informasi, 3) mencari data dalam eksperimen, mengorganisasikannya, 4) merumuskan, dan menjelaskan dan 5) menganalisis proses penelitian. Tahap-tahap ini merupakan metode yang baik dilakukan oleh guru ketika melaksanakan pembelajaran dikelas karena dengan menampilkan beberapa tahapan dalam pembelajaran inquiri siswa tidak hanya menghafalkan banyak rumus dan menghitung saja, tetapi juga menampilkan gejala-gejala fisika yang dapat mereka temui dalam kehidupan mereka sehari-hari sehingga mereka dapat memaknai konsep-konsep fisika yang diajarkan yang pada akhirnya dapat menciptakan proses pembelajaran fisika bermakna (Trisno, 2012).

Pemaparan tentang penelitian sebelumnya yang berkaitan dengan pembelajaran inquiry training. diantaranya : hasil penelitian Pandey et all., (2011) bahwa inquiry training berpengaruh signifikan terhadap prestasi akademik siswa. Pengajaran dengan model inquiry training dinyatakan lebih efektif daripada pengajaran melalui metode konvensional. Trisno (2012) mengatakan bahwa terdapat perbeaan hasil belajar antara siswa yang mengikuti model pembelajaran inquiry training dengan model pembelajaran konvensional pada 
pokok bahasan kalor siswa SMP Negeri 9 Palu.

Kesimpulan

Indahwati, (2012) menunjukkan bahwa model pembelajaran inquiry training dapat digunakan untuk mendorong siswa lebih aktif dalam belajar sehingga siswa akan mendapatkan pemahaman yang lebih baik mengenai materi dan akan lebih tertarik terhadap materi yang disampaikan. Keterlibatan aktif siswa terbukti dapat meningkatkan prestasi belajar dan sikap siswa terhadap materi pelajaran. Penerapan model inquiry training juga mampu membuat siswa saling bekerja sama melalui diskusi kelompok yang mengharuskan siswa memberikan masukan kepada siswa lain sehingga siswa yang kurang mampu lebih termotivasi dalam memperlajari materi yang kurang dimengerti. Indahwati, 2012)

Penggunaan media juga mempunyai peranan penting dalam penyampaian pembelajaran. Media pembelajaran berfungsi untuk membawa informasi antara sebuah sumber dan sebuah penerima (guru kepada siswa). Salah satu media dalam pembelajaran adalah mind mapping. Menurut Buzan (2006), mind mapping merupakan alat paling hebat untuk membantu otak berpikir secara teratur. Mind map adalah cara mencatat yang kreatif, efektif, memetakan pikiran-pikiran secara menarik, mudah dan berdaya guna.

Tujuan penelitian ini adalah untuk mengetahui penerapan model pembelajaran inquiry training berbasis mind mapping dan mengetahui aktivitas proses pembelajaran inquiry training di kelas X SMA N 1 Simanindo T.P. 2014/2015.
Tabel 1. Fase model pembelajaran

\begin{tabular}{|c|c|}
\hline Fase & Perilaku Guru \\
\hline $\begin{array}{l}\text { 1). Fase } 1 \\
\text { Menghadapkan } \\
\text { pada masalah }\end{array}$ & $\begin{array}{l}\text { Menjelaskan } \\
\text { prosedur-prosedur } \\
\text { penelitian, } \\
\text { menjelaskan } \\
\text { perbedaan- } \\
\text { perbedaan. }\end{array}$ \\
\hline $\begin{array}{l}\text { 2). Fase } 2 \\
\text { Mengumpulkan } \\
\text { data verifikasi }\end{array}$ & $\begin{array}{l}\text { Memverifikasi } \\
\text { hakikat objek dan } \\
\text { kondisinya, } \\
\text { memverifikasi } \\
\text { peristiwa dari } \\
\text { keadaan } \\
\text { permassalahan. }\end{array}$ \\
\hline $\begin{array}{l}\text { 3). Fase } 3 \\
\text { Mengumpulkan } \\
\text { data } \\
\text { eksperimentasi }\end{array}$ & $\begin{array}{l}\text { Memisahkan } \\
\text { variabel yang } \\
\text { relevan, } \\
\text { menghipotesiskan } \\
\text { (serta menguji) } \\
\text { hubungan kausal. }\end{array}$ \\
\hline $\begin{array}{l}\text { 4).Fase } 4 \\
\text { Mengorganisasikan, } \\
\text { memformulasi kan } \\
\text { suatu penjelasan }\end{array}$ & $\begin{array}{l}\text { Memformulasikan } \\
\text { aturan dan } \\
\text { penjelasan. }\end{array}$ \\
\hline $\begin{array}{l}\text { 5). Fase } 5 \\
\text { Analisis proses } \\
\text { inquiry }\end{array}$ & $\begin{array}{l}\text { Menganalisis } \\
\text { strategi penelitian } \\
\text { dan } \\
\text { mengembangkan } \\
\text { yang paling efektif. }\end{array}$ \\
\hline
\end{tabular}

\section{METODE PENELITIAN}

Populasi dalam penelitian ini adalah seluruh siswa kelas X SMA Negeri 1 Simanindo T.P. 2014/2015 yang terdiri dari 5 kelas paralel. Sampel ditentukan dengan cara cluster random sampling. Sampel diambil dari populasi yaitu sebanyak satu kelas sebagai kelas treatment yang diajarkan dengan menggunakan model pembelajaran inquiry training berbasis mind mapping.

Jenis penelitian ini adalah penelitian pre-eksperimental design. Penelitian ini melibatkan 1 kelas yang diberi perlakuan yaitu berupa tes. Tes yang dilakukan yaitu pretes dan postes. Desain penelitiannya 
berupa one group pretest posttest design. Desain group pretest posttest design ditunjukkan Tabel 2.

Tabel 2. Control Group PretestPosttest Design

\begin{tabular}{|l|l|l|l|}
\hline Kelas & $\begin{array}{l}\text { Pretes } \\
\boldsymbol{t}\end{array}$ & Perlakuan & Posttest \\
\hline $\begin{array}{l}\text { Treat } \\
\text { ment }\end{array}$ & $\mathrm{O}_{1}$ & $\mathrm{X}$ & $\mathrm{O}_{2}$ \\
\hline
\end{tabular}

(Sugiyono, 2008)

Keterangan:

$\mathrm{O}_{1}$ : nilai pretes kelas treatment

$\mathrm{O}_{2}$ : nilai postes kelas treatment

$\mathrm{X}$ : model pembelajaran inquiry

training berbasis mind map

Alat pengumpul data dalam penelitian ini adalah evaluasi belajar berupa pretes dan postes untuk kelas treatment. Bentuk tes evaluasi pretes dan postes adalah bentuk essay test atau tes uraian sebanyak 8 soal. Instrument penelitian divalidasi oleh dua orang dosen Pendidikan Fisika Unimed dan satu orang guru bidang studi fisika di SMA Negeri 1 Simanindo.

Analisis data yang digunakan adalah Uji McNemar. Uji McNemar yang dirumuskan dengan:

$$
X^{2}=\frac{(|A-D|-1)^{2}}{A+D}
$$

Dimana taraf kesalahan 5\% dan $\mathrm{dk}=1$.

Panduan untuk menguji signifikasi setiap perubahan pada uji McNemar dapat dilihat pada Tabel 3.

Tabel 3. Tabel Segiempat ABCD sebagai Panduan untuk Menguji Signifikasi Setiap Perubahan pada Uji McNemar

\begin{tabular}{|c|c|c|}
\hline \multirow{2}{*}{$\begin{array}{c}\text { Sebelum } \\
\text { (pretest) }\end{array}$} & \multicolumn{2}{|c|}{ Sesudah (posttest) } \\
\cline { 2 - 3 } & - & + \\
\hline+ & $\mathrm{A}$ & $\mathrm{B}$ \\
\hline- & $\mathrm{C}$ & $\mathrm{D}$ \\
\hline
\end{tabular}

\section{HASIL DAN PEMBAHASAN}

Berdasarkan data hasil penelitian di SMA N 1 Simanindo, hasil pretes diperoleh nilai terendah 3 dan nilai tertinggi 31 dengan nilai rata-rata 13,9 simpangan baku 6,52. Perolehan hasil postes diperoleh nilai terendah 19 dan tertinggi nilai 83 dengan nilai rata-rata 56,08, simpangan baku 19,32.

Pengujian hipotesis dalam penelitian ini meliputi uji perbandingan antara nilai pretes (sebelum ada perlakuan) dan nilai postes (sesudah ada perlakuan). Untuk menguji hipotesis digunakan uji non parametrik McNemar. Hasil analisis data dapat disajikan pada Tabel 4.

Tabel 4. Perhitungan Uji McNemar

\begin{tabular}{|c|c|c|c|c|c|c|}
\hline $\begin{array}{l}\text { No } \\
\text { Soal }\end{array}$ & A & B & $\mathrm{C}$ & D & $X^{2}$ & Ket \\
\hline 1 & 1 & 0 & $\begin{array}{l}1 \\
1\end{array}$ & 24 & 19,36 & $\begin{array}{l}\text { Signifika } \\
\mathrm{n}\end{array}$ \\
\hline 2 & 0 & 1 & $\begin{array}{l}2 \\
3 \\
\end{array}$ & 12 & 10,08 & $\begin{array}{l}\text { Signifika } \\
\mathrm{n}\end{array}$ \\
\hline 3 & 1 & $\begin{array}{l}1 \\
1 \\
\end{array}$ & 2 & 22 & 17,39 & $\begin{array}{l}\text { Signifika } \\
\mathrm{n}\end{array}$ \\
\hline 4 & 1 & $\begin{array}{l}2 \\
5 \\
\end{array}$ & 0 & 10 & 5,81 & $\begin{array}{l}\text { Signifika } \\
\mathrm{n}\end{array}$ \\
\hline 5 & 1 & 3 & $\begin{array}{l}1 \\
4\end{array}$ & 18 & 13,47 & $\begin{array}{l}\text { Signifika } \\
\mathrm{n}\end{array}$ \\
\hline 6 & 0 & 3 & 4 & 29 & 27,03 & $\begin{array}{l}\text { Signifika } \\
\mathrm{n}\end{array}$ \\
\hline 7 & 0 & 0 & $\begin{array}{l}1 \\
3\end{array}$ & 23 & 21,04 & $\begin{array}{l}\text { Signifika } \\
\mathrm{n}\end{array}$ \\
\hline 8 & 0 & 1 & 7 & 28 & 26,03 & $\begin{array}{l}\text { Signifika } \\
\mathrm{n}\end{array}$ \\
\hline $\begin{array}{l}\text { Tota } \\
1\end{array}$ & 4 & $\begin{array}{l}4 \\
4 \\
\end{array}$ & $\begin{array}{l}7 \\
4 \\
\end{array}$ & 166 & $\begin{array}{l}152,4 \\
8\end{array}$ & $\begin{array}{l}\text { Signifika } \\
\mathrm{n}\end{array}$ \\
\hline \multicolumn{5}{|c|}{ Rata-rata } & 19,06 & $\begin{array}{l}\text { Signifika } \\
\mathrm{n}\end{array}$ \\
\hline
\end{tabular}

Keterangan :

A : Siswa yang pretes DM, postes TDM

B : Siswa yang pretes DM, postes DM

C : Siswa yang pretes TDM, postes TDM

D : Siswa yang pretes TDM, postes $\mathrm{DM}$ 
DM : Dapat Menyelesaikan

TDM: Tidak dapat menyelesaikan

Uji McNemar di peroleh $X^{2}$ tabel $=$ 3,84 lebih kecil dari $X^{2}$ hitung rata-rata $=19,06$ untuk $d b=1$ dan $a=5 \%$, menunjukkan bahwa terdapat perubahan kemampuan siswa yang signifikan dalam penerapan model pembelajaran inquiry training berbasis mind mapping pada materi suhu dan kalor.

Peningkatan hasil belajar dengan menerapkan model pembelajaran inquiry training berbasis mind mapping disebabkan adanya keterlibatan siswa secara langsung untuk membuat hipotesis terhadap masalah yang disajikan, mencari informasi, melakukan percobaan, mengumpulkan data-data percobaan dan menemukan konsep/makna dari apa yang telah mereka peroleh.

Pengamatan aktivitas siswa selama proses pembelajaran dilakukan sebanyak tiga kali pertemuan setelah melakukan pretes. Berdasarkan pengamatan aktivitas siswa kelas eksperimen didapatkan informasi bahwa rata-rata aktivitas dari pertemuan pertama hingga pertemuan ketiga mengalami peningkatan.Aspek penilaian/ indikator dari aktivitas yang paling menonjol dalam penelitian ini yaitu indikator melakukan diskusi. Ratarata aktivitas melakukan diskusi sebesar $75 \%$.

Menurut penulis, media mind mapping yang digunakan dalam menyampaikan materi dapat mempermudah siswa dalam mengerti apa yang sedang dipelajari. Ini ditunjukkan dari hasil kerja kelompok siswa dalam mengerjakan mind mapping.
Kelemahan yang didapati dalam penelitian ini yaitu tidak semua siswa berperan aktif di dalam kegiatan kelompok, sehingga kegiatan di dalam kelompok didominasi oleh siswa yang sama. Saat diskusi berlangsung, terkadang terjadi kegaduhan-kegaduhan diantara siswa dimana ada siswa yang mengambil kesempatan untuk bermain-main atau membicarakan hal-hal di luar materi, sehingga peneliti berusaha mengkondusifkan siswa dengan membimbing dan mengarahkan siswa untuk kembali berdiskusi.

\section{KESIMPULAN DAN SARAN}

\section{Kesimpulan}

(1) Penerapan model inquiry training dapat meningkatkan keaktifan siswa dalam proses pembelajaran. ditinjau dari hasil dengan kategori rata-rata aktivitas.

(2) Ada pengaruh model pembelajaran inquiry training berbasis mind mapping terhadap hasil belajar siswa.

\section{Saran}

Saran yang dapat peneliti ajukan berdasarkan pembahasan adalah, model pembelajaran inquiry training sebaiknya dijadikan alternatif pembelajaran bagi guru untuk meningkatkan pemahaman siswa dalam pelajaran fisika..

\section{DAFTAR PUSTAKA}

Buzan, T., (2006), Buku Pintar Mind Map. Gramedia Pustaka Utama, Jakarta.

Indahwati, T, S., (2012), Penerapan Model Inquiry Training Melalui Teknik Peta Konsep dan Teknik Puzzle Ditinjau dari Tingkat dan Kemampuan 
Aktivitas Belajar dan Kemampuan Memori, Jurnal Inkuiri Pasca Sarjana Uns ISSN: 2252-7893, Vol 1, No 3 : hal : 258-265

Kadughothel, S., (2015), A Study on Developing Scientific Attitude Through

Inquiry Training Model Among School Children, International Journal of Research \& Development in Technology and Management ScienceKailash : pp 125-127

Kurnianto, (2010), Jurnal Pendidikan Fisika Indonesia 6 (2010) 6-9, Universitas Negeri Semarang, Semarang.

Pandey, A., Nanda, G.K,. and Ranjan, V., (2011), Effectiveness of Inquiry Training Model over Conventional Teaching Method on Academic Achievement of Science Students in India, Journal of Innovative Research in Education 1(1) pp : 7-20.

Sugiyono., (2008), Metode Penelitian Pendidikan, Alfabeta, Bandung.

Trisno dan Kendek, Y., (2012), Pengaruh Model Pembelajaran Training Inquiry Terhadap Hasil Belajar Pada Pokok Bahasan Kalor

Siswa SMP Negeri 9 Palu, Jurnal Pendidikan Fisika Tadulako (JPFT)Vol. 2 No. ISSN 23383240 hal : 14-20

Vaishnav, R.S., (2013), Effectiveness of Inquiry Training Model for Teaching Science, journal of Chirayu, $K C$ Bajaj College of Education VOL-I, ISSUE-V: pp 1216-1220. 